\title{
Idiosyncratic Volatility and Cross-section of Stock Returns: Evidences from India
}

\author{
Prashant Sharma \\ Assistant Professor and Area Chair (Finance and Accounts) \\ Jaipuria Institute of Management, Jaipur, India \\ E-mail: prashantsharma1989@gmail.com \\ Brajesh Kumar \\ Assistant Professor, Department of Economics \\ National Institute of Financial Management, Faridabad, Haryana, India \\ E-mail: brajesh@nifm.ac.in
}

\begin{abstract}
Received: Jan. 19, $2016 \quad$ Accepted: Feb. 22, $2016 \quad$ Published: June 1, 2016
doi:10.5296/ajfa.v8i1.8898 URL: http://dx.doi.org/10.5296/ajfa.v8i1.8898
\end{abstract}

\begin{abstract}
The present study examines the cross-sectional pricing ability of idiosyncratic volatility (IV) in Indian stock market and investigates the relationship amongst expected idiosyncratic volatility (EI), unexpected idiosyncratic volatility (UI), and cross-section of stocks returns. The study uses ARIMA $(2,0,1)$ model to IV into EI and UI. The stocks returns are regressed on IV, EI and UI using Newey-West (1987) corrections, in order to investigate their empirical relationship. The study finds that IV is positively related with stock returns. Further the IV significantly explains the cross-section of stock returns in Indian context. After imposing control over UI, as it is highly correlated with unexpected returns, the inter-temporal relationship between EI and expected returns turns out to be positive.
\end{abstract}

Keywords: idiosyncratic risk, asset pricing, Fama-French factor model, Newey-West statistics, arima

JEL Classification: C30, G11, G12 


\section{Introduction}

Asset pricing theories focus on the inter-temporal relationship between risk and return. The traditional theories focus majorly on the systematic risks but not on idiosyncratic risk, as it was assumed that perfect diversification in the portfolio can eliminate the idiosyncratic risk (Markowitz, 1959; Sharpe, 1964; Treynor, 1961; and Lintner, 1965). But, in real market scenario, it is very hard to diversify the portfolio perfectly. As mentioned by Goyal and Clara (2003), the reasons for not attaining fully diversified portfolios are transaction costs, taxes, concentration exposure that restrict the capacity of employees to sell their holdings received under employee compensation plans, private information about individual stocks, prone to invest in familiar stocks and irrationality of investors. To overcome such issue, in past two decades, the researchers have paid considerable attention to the role of IV in determining the excess returns. Considering the importance of IV in asset pricing theory, Merton (1987), in his theoretical model (assuming investor's under-diversified portfolio) emphasized that it can have significant role in determining excess returns. Following the theoretical model of Merton (1987), numerous works had been conducted to see the inter-temporal relationship between IV and excess returns, which can be divided majorly into three categories; first category focusing on the time series trend ofIV in asset pricing process; second, emphasizing on the inter-temporal relationship between idiosyncratic volatility and future returns of stocks; and the third is on the time series association and predicting power of idiosyncratic volatility and cross-section of stock's excess returns.

The study conducted by Campbell et. al., (2001) was in support of first branch of literature which focused to analyze the time series trends in idiosyncratic volatility. They divided total volatility into two i.e., firm volatility and the market volatility. Employing data for period of 1962-1997, the results showed that the firm level volatility had increased over a period of time relative to market volatility and as result of that the explanatory power of market models had been declined. Apart from this, the number of stocks needed for achieving a given level of diversification had increased. In line with second branch of literature, the predictability of stock returns with different risk measures was tested by Goyal and Clara (2003) for period of July 1962 to December 1999 and showed that there is significant positive relationship between average stock variance (largely idiosyncratic risk ) and market returns. These results were robust after controlling for various macroeconomic risk indicators ${ }^{\mathrm{i}}$. These empirical evidences indicate the significant role of IV in asset pricing theory. The study conducted by Anget. al., (2006), provides systematic investigation of pricing of IV in US context using the data from January 1986 to December 2000. This study examines the cross-sectional pricing ability of IV and provides a puzzle which is commonly known as idiosyncratic risk puzzle, and documented a negative relationship between IV and stock returns. These findings were robust after controlling for various firm characteristics ${ }^{\mathrm{ii}}$. The focus of our study is on the second and third branch of literature; focusing on the inter-temporal relationship association between IV and stock's excess returns; and the cross-sectional pricing ability of IV in Indian stock market.

The relationship between IV and cross-section of stock returns have shown mixed outcomes, some studies reported the significantly positive relationship while others have documented 
that either there is no relationship or negative relationship. The studies conducted by Goyal and Clara (2003) and Spiegal and Wang (2005) presented significant positive relationship between IV and stock returns. The findings of Goyal and Clara (2003) were opposed by Bali et. al., (2005), as they argued that the results were driven by small stocks traded on NASDAQ, and was in part due to a liquidity premium. There were no evidences of relationship between value-weighted portfolio returns and the median value-weighted average stock volatility.

The recent studies conducted by Fu (2009), Boehme et. al., (2009), Chua et. al., (2010)and Marcelo et. al., (2012) emphasized on the significant positive relationship between IV and cross-section of stocks returns while the studies of Anget. al., (2006, 2009), Guo and Savickas (2010) and Bley and Saad (2012) documented the negative relationship. Some other studies by Bali et. al., (2005) and Bali and Cakici (2008) reported no significant relationship between IV and cross-section of stock returns. The relationship between cross-section of stock returns and IV are sensitive to model specification and the sample data used to measure the idiosyncratic risk and these mixed evidences are mainly due to lack of consistency choice of variable used to estimate idiosyncratic volatility. Some of the existing studies have considered the total IV and while others have used the EI. Fu (2009) addressed this issue and emphasized on the use of EI determined ex-ante, not the total idiosyncratic volatility, since the objective is to examine its relationship with expected returns. In addition, French, Schwert and Stambaugh (1987) indicated that the use of total volatility may present some obscure relationship between the market returns and market volatility, and suggested to decompose the total volatility to predictive and un-predictive components. Following this decomposition approach, Chua et. al., (2010) decomposed the IV into two, EI and UI and reported that UI controls for unexpected component of returns. The EI explains cross-section of stock returns significantly and have a positive relationship with returns. As discussed above, numerous evidences on relationship between idiosyncratic volatility and cross-section of stocks returns exist in global context, but there is dearth of literature in Indian context.

In this background, the present study has been designed to: examine the cross-sectional pricing ability of idiosyncratic risk in Indian context; and investigates the empirical relationship amongst EI, UI, and stocks excess returns. The present study contributes in the existing body of literature by improving the international evidences with the exclusive in-depthanalysis of the Indian market which is relatively less explored. The study follows the approach of Chua et. al., (2010) for estimation of idiosyncratic volatility. Similar to French, Schwert and Stambaugh (1987), the study employs ARIMA $(2,0,1)$ or ARMA $(2,1)$ model for decomposition of IV into EI and UI.

The study employs monthly data from 2001 (FY) to 2012 (FY) of non banking and financial companies of BSE 500 index. For estimation of IV, the monthly Fama French (1993) factors $^{\mathrm{iii}}$ are regressed on monthly returns of the individual sample firms. The square of the resulting regression residuals are treated as IV of the particular firm. Additionally, for decomposition of IV, ARMA $(2,1)$ model is pressed into service for each company and the fitted values are termed as the EI and the residuals are termed as UI. In order examine the cross-section pricing ability of IV, EI and UI, the cross-sectional regression analysis are conducted with the estimation of Newey-West (1987) t-statistics. The robustness of the 
relationship is tested after controlling for various firm characteristics such as market capitalization and book to market equity ratio.

The study finds a significant positive relationship between EI and stocks expected returns, that is consistent with studies of Merton (1987), Fu (2009) and Chua et. al., (2010) which reported the significant robust relationship between EI and expected returns. Our results are different with the studies of Anget. al., $(2006,2009)$ indicating negative relationship between the two, wherein Bali and Cakici (2008) found no significantly robust relationship between IV and expected returns.

The study has been structured in following sections. Section 2 presents the data and empirical methodology for estimation of IV and section 3 presents the empirical results and findings of the study and we conclude with section 4.

\section{Data and Methodology for Estimation of Volatility}

The study employs monthly data on stocks returns, market returns, 91 dayst-bills rates, SMB and HML of BSE 500 companies (except banking and financial institutions) from 2001(FY) to 2012 (FY). The data are collected from CMIE (Center for Monitoring Indian Economy) PROWESS 4.0 data base and the Indiastatdsatabase. In order to maintain the consistency in the data, only those firms are considered which are having data for full sample period; this number turns out to be 273 firms. The data on variables; stock excess returns and market excess returns are derived by subtracting the 91 days t-bills rates from individual firmreturns and market returns series. The factors SMB, HML are constructed using Fama-French (1992) methodology.

\subsection{Construction of Fama-French (1992) Factors}

The factors SMB and HML are constructed from a two-by-three sort on size and book-to-market value. At the end of March of each year from 2001 to 2011, all stocks are ranked on market capitalization (or size) and book to market value. The median value of the size is used as a size break point to split all stocks into two groups, small (S) and big (B). The stocks shorted on book to market value are divided into three book-to-market groups based on the break points for the bottom 30\% (L), middle 40\% (M), and top 30\% (H). Monthly equally-weighted returns on the six portfolios are calculated from April of year y to March of year $y+1 . S M B$ is the difference, each month, between the simple average of the returns on the three small portfolios $(\mathrm{S} / \mathrm{L}, \mathrm{S} / \mathrm{M}$, and $\mathrm{S} / \mathrm{H})$ and the simple average of the returns on the three big stocks $(\mathrm{B} / \mathrm{L}, \mathrm{B} / \mathrm{M}$, and $\mathrm{B} / \mathrm{H})$. HML is the difference, each month, between the simple average of the returns on the two high book to market portfolios $(\mathrm{S} / \mathrm{H}$ and $\mathrm{B} / \mathrm{H})$ and the simple average of the returns on the two low book to market portfolios ( $\mathrm{S} / \mathrm{L}$ and $\mathrm{B} / \mathrm{L})$.

\subsection{Idiosyncratic Volatility: Definition and Estimation}

To estimate the idiosyncratic volatility, Fama-French (1993) regression is conducted using the monthly returns of all stocks.

$$
r_{i, t}=\alpha_{i, t}+\beta_{i, t} R m_{i, t}+\beta_{i, t 2} S M B_{i, t}+\beta_{i, t 3} H M L_{i, t}+\varepsilon_{i, t}
$$


Where $r_{i, t}$ represents the monthly excess returns on stock $\mathrm{i}$ on month t. Similarly $R m_{i, t}$ represents the monthly excess returns of BSE 500 index, $S M B_{i, t}$ is the return difference on size factor and $H M L_{i, t}$ is the return difference on value factor. $\alpha_{i, t}$ is coefficient and $\beta_{i, t}$ are parameters for each factors. Following the Anget. al., (2006) and Chua et. al., (2010) methodology, the idiosyncratic volatility of stock $i$ in month $t$ is defined as;

$$
I V_{i, t}=\sum \varepsilon_{{ }_{i, t}}
$$

Where $I V_{i, t}$ is the idiosyncratic volatility measure for firm $\mathrm{i}$ in month $\mathrm{t}$ which is the square of the Fama-French regression residuals $\left(\varepsilon 2_{i, t}\right)$. To decompose the idiosyncratic volatility into expected and unexpected components, $\operatorname{ARMA}(2,1)$ model is used. For each stock, using monthly data, the following time series regression is performed;

$$
I V_{i, t}=\theta_{0}+\theta_{1} I V_{i, t-1}+\theta_{2} I V_{i, t-2}-\phi_{1} \xi_{t-1}
$$

Here $I V_{i, t-1}$ and $I V_{i, t-2}$ are the lagged auto-regressive terms of order one and order two and $\xi_{t-1}$ is moving average terms of first order. Following Chua et. al., (2010), the fitted values of regression equation 3 are defined as EI and the residuals are termed as UI.

\subsection{Descriptive Statistics}

Table 1. Descriptive Statistics

\begin{tabular}{llll}
\hline & IV & EI & UI \\
\hline Mean & 0.035769 & 0.033425 & 0.002344 \\
Median & 0.018008 & 0.01773 & 0.000004 \\
Std. Dev. & 0.119635 & 0.104803 & 0.029507 \\
Skewness & 11.0647 & 12.29724 & 16.24822 \\
Kurtosis & 129.1697 & 167.6131 & 266.9859 \\
\hline
\end{tabular}

Note: The sample is from June 2001 to March 2012. At every month, for each firm, the IV (idiosyncratic volatility) is calculated by following equation 2 and EI (expected idiosyncratic 
volatility) and UI (unexpected idiosyncratic volatility) are estimated using equation 3. In order to provide point estimate, the cross-sectional averages of IV, EI and UI are reported.

Table 1 reports the summary statistics; mean, median, standard deviation, skewness and kurtosis of the cross-sectional series of IV, EI and UI. The cross-sectional mean of IV in Indian stock market is 0.036 and the standard deviation is 0.12 . The mean IV of Indian market is higher than those reported for US context; while standard deviation is lower (see Chua et. al., 2010, Zang 2004); indicating that IV is less volatile in Indian context. The mean of EI is 0.032 which is near to IV mean but EI is less volatile than IV since its standard deviation 0.1048 . UI is having very low mean value of 0.0023 with standard deviation of 0.03 , showing less volatile behavior.

\section{Results and Discussions}

\subsection{Cross-sectional Regression of Returns on IV}

Following regression is performed to investigate the relationship between cross-section of stock returns and idiosyncratic volatility.

$$
r_{i, t}=\sigma_{0}+\sigma_{1} I V_{i, t}+\eta_{i, t}
$$

Table 2. Cross-Sectional Regression of Returns on IV and Control Variables (Size and Value)

\begin{tabular}{|c|c|c|c|c|}
\hline \multirow[t]{2}{*}{ Variable } & \multicolumn{2}{|l|}{ Model 1} & \multicolumn{2}{|l|}{ Model 2} \\
\hline & Parameter & t-statistics & Parameter & $\mathrm{t}$-Statistic \\
\hline $\mathrm{C}$ & -0.04323 & -3.0709 & -0.10506 & -0.49675 \\
\hline IV & $0.48034 *$ & 3.4629 & $0.616778^{*}$ & 2.618798 \\
\hline LNBEME & & & 0.007564 & 0.218268 \\
\hline LNMCAP & & & $0.026027 * *$ & 0.807847 \\
\hline R-squared & 0.153554 & & 0.173427 & \\
\hline
\end{tabular}

Note: The sample is from June 2001 to March 2012. At each month, the cross-section of returns is regressed on cross-section of IV of 273 sample firms of BSE 500. The table reports the time-series average of parameters and the Newey-West (1987) adjusted t-statistics. The 
adjusted $\mathrm{R}^{2}$ value is also reported. Later on this regression were performed after controlling for LNMCAP (size) and LNBEME (value) effect. * represent significant at $1 \%$ level of significance and $* *$ for $5 \%$ level of significance.

Model 1 of table 2 reports the time series means of parameters and Newey-West (1987) t-statistics for regression of returns on IV. The coefficient of IV is -0.04 which is very low and insignificant while the parameter of IV is 0.48 which is positive and significant at $1 \%$ level of significance. This indicates that in Indian stock market, the IV is having significant explanatory power to predict the stock returns.

The existing asset pricing literature had documented that the anomaly factors; market capitalization and book to market ratio (Fama French, 1992) had significant explanatory power of explaining variation in the cross-section of stock returns. In order to test the robustness of the results reported in model 1 of table 2, cross-section of returns is regressed on IV after controlling for variables i.e., the logarithmic value of market capitalization and book to market ratio of individual firms.

$$
r_{i, t}=\sigma_{0}+\sigma_{1} I V_{i, t}+\sigma_{2} \ln \text { beme }_{i, t}+\sigma_{3} \ln \operatorname{mcap}_{i, t}+\eta_{i, t}
$$

The results are reported in the model 2 of table 2. The parameter of IV, after controlling for control variables, is 0.62 which is higher than those reported in model 1 . It is significant at $1 \%$ level of significance, and the explanatory power (adjusted $\mathrm{R}^{2}$ ) of this model has improved after controlling for anomaly factors. This clearly indicates that IV is having significant explanatory power to explain cross-sectional variation in stock's returns and the impact of IV is positive and significant.

Recent literature on the relationship between idiosyncratic volatility and stock returns advocates the decomposition of IV into EI and UI. Fu (2009) addressed this issue and emphasized the use of EI determined ex-ante and not the total idiosyncratic volatility.

\subsection{Cross-Sectional Pricing Ability of EI and UI}

To investigate the relationship of EI, UI and returns, the returns of companies are regressed on EI using following cross-sectional regression;

$$
r_{i, t}=\vartheta_{0}+\vartheta_{1} E I_{i, t}+\eta_{i, t}
$$


Table 3. Cross-Sectional Regression of Stock Returns on EI and Both EI and UI

\begin{tabular}{llllll}
\hline & Model 3 & & & Model 4 & \\
\cline { 1 - 1 } \cline { 5 - 6 } Variable & Parameter & t-Statistic & & Parameter & t-Statistic \\
\hline C & -0.0442 & -1.3184 & & -0.0441 & -1.482 \\
EI & $0.2596^{* *}$ & 0.3026 & & $0.24073^{* *}$ & 0.4575 \\
UI & & & $0.525245^{*}$ & 2.0831 \\
Adjusted $\mathrm{R}^{2}$ & 0.1089 & & 0.1610 & \\
\hline
\end{tabular}

Note: The sample is from June 2001 to March 2012. At each month, the cross-section of returns is regressed on EI of 273 sample firms of BSE 500. The table reports the time-series average of parameters and the Newey-West (1987) adjusted t-statistics. The adjusted $\mathrm{R}^{2}$ value is also reported. Later on this regression were performed after controlling for UI. * represent significant at $1 \%$ level of significance and $* *$ for $5 \%$ level of significance.

Model 3 of table 3presents the mean of cross-sectional regression result of returns on EI. The parameter of EI is 0.26 , which is statistically significant at $5 \%$ significance level. This indicates that EI is having significant explanatory power to explain cross-sectional variation in expected stock returns, but EI doesn't outperform in comparison to IV.

Further the relationship of EI and returns is explored after controlling for UI and following cross-sectional regression equation is used;

$$
r_{i, t}=\vartheta_{0}+\vartheta_{1} E I_{i, t}+\vartheta_{2} U I_{i, t}+\eta_{i, t}
$$

Model 4 of table 3 represents the results of the cross-sectional regression of returns on EI and UI. The parameter of UI is 0.5252 which is significant at $1 \%$ level of significance, supports the findings of Chua et. al., (2010), who reported that UI controls for unexpected variation in the future stock returns. The Parameter of EI is 0.24 at $5 \%$ level of significance. This parameter value is marginally lower than the parameter of EI (when there was no control over UI). These results suggest that in Indian context, EI's explanatory power for explaining cross-section of expected returns, sustains after UI controlling for unexpected component of future stocks returns. The results also suggest that the impact of EI on returns is economically significant. A $1 \%$ increase in the EI will lead to $0.24 \%$ increase in the expected stock returns. The relationship of EI and returns is positive, which is in line with the existing literature. After controlling for unexpected returns, the EI's explanatory power should increase but we don't find any evidences in Indian context. In order to re-examine and test the robustness of 


\section{Macrothink}

Asian Journal of Finance \& Accounting

ISSN 1946-052X 2016, Vol. 8, No. 1

this relationship, the study uses the market capitalization and book to market ratio (Fama French, 1992) as control variables.

\subsection{Control Variable and Relationship of EI, UI and Returns}

To test the robustness of the relationship of EI and returns, these factors (market capitalization and book to market ratio) are introduced in following cross-sectional regression equation;

$$
r_{i, t}=\vartheta_{0}+\vartheta_{1} E I_{i, t}+\vartheta_{2} U I_{i, t}+\vartheta_{3} \ln \operatorname{mcap}_{i, t}+\vartheta_{4} \ln \text { beme }_{i, t}+\eta_{i, t}
$$

Table 4. Cross-sectional Regression with Control Variables (Size and Value)

\begin{tabular}{llr}
\hline Variable & Parameter & t-Statistic \\
\hline & & \\
C & -0.1058 & -0.4271 \\
EI & $0.55009^{* *}$ & 0.55381 \\
UI & $0.66519^{*}$ & 1.95668 \\
LNBEME & 0.00701 & 0.16803 \\
LNMCAP & $0.02441^{* *}$ & 0.76829
\end{tabular}

Adjusted R-squared

0.17999

Note: The sample is from June 2001 to March 2012. At each month, the cross-section of returns is regressed on EI after controlling for UI, market capitalization and book to market ratio of 273 sample firms of BSE 500. The table reports the time-series average of parameters and the Newey-West (1987) adjusted t-statistics. The adjusted $\mathrm{R}^{2}$ value is also reported. * represent significant at $1 \%$ level of significance and $* *$ for $5 \%$ level of significance.

Table 4 reports the mean of parameters and Newey West (1987) t-statistics of the cross-sectional regression of returns on EI, after controlling for UI, market capitalization and book to market equity ratio. The parameter of $\mathrm{EI}$ is 0.55 , which is significantly higher than the parameter $(0.24)$ reported in model 4 of table 3 , where no control were imposed on the relationship between returns and EI except UI. After controlling for UI along with market capitalization and book to market ratio, the explanatory power of EI has significantly improved. The parameter is statistically significant at 5\% level of significance level; clearly 
indicates that the EI explain the cross-section of stock returns significantly in Indian market. These findings are consistent with Fu (2009) and Chua et. al., (2010).

\section{Conclusion}

The study aims to examine the relationship of IV and cross-section of stock returns in Indian stock market. The existing literature suggests two approaches to investigate the relationship between idiosyncratic volatility and returns; first to regress stock returns on IV and second is to decompose the IV into expected and unexpected components and then find the resulting relationship. Considering the second approach, the IV is decomposed into EI and UI, as Fu (2009) emphasized the use of EI determined ex-ante and not the total IV to examine its impact on cross-section of stock returns.

The findings of the study suggest that IV and EI explain the cross-section of stock returns significantly in Indian context. The explanatory power of EI doesn't improve after controlling for UI, but when we control for the Fama French (1992) factors i.e., market capitalization and book to market equity, the explanatory power of EI improves significantly and then explains $55 \%$ of cross-sectional variation in expected stock returns. The relationship is positive, indicates that a $1 \%$ increase in EI will lead to $0.55 \%$ increase in expected stock returns. The results are consistent with the study of Spiegel and Wang (2005), Fu (2009) and Chua et. al., (2010), as they documented a significant positive relationship between expected returns, EI and UI. The findings don't support Anget. al., $(2006,2009)$ and Bali and Cakici (2008)because the former have documented negative relationship while later reported no significant relationship between IV and expected returns. The study concludes with a note that along with the systematic risk, the idiosyncratic risk should also be considered while determining the asset prices in Indian stock market.

\section{References}

Ang, A., Hodrick, R., Xing, \& Y., Zhang, X. (2006). The Cross-Section of Volatility and Expected Returns. Journal of Finance, 61, 259-299. http://dx.doi.org/10.1111/j.1540-6261.2006.00836.x

Ang, A., Hodrick, R.J., Xing, Y., \& Zhang, X. (2009). High Idiosyncratic Volatility and Low Returns: International and Further U.S Evidence. Journal of Financial Economics, 91, pp 1-23. http://dx.doi.org/10.1016/j.jfineco.2007.12.005

Bali, T., \& Cakici, N. (2008). Idiosyncratic Volatility and the Cross-Section of Expected Returns?. Journal of Financial and Quantitative Analysis, 43, 29-58. http://dx.doi.org/10.1017/S002210900000274X

Bali, T., Cakici, N., Yan, X.,\& Zhang, Z. (2005). Does Idiosyncratic Risk Really Matter? Journal of Finance, 60, 905-929. http://dx.doi.org/10.1111/j.1540-6261.2005.00750.x

Bley, J., Saad, M. (2012). Idiosyncratic Risk and Expected Returns in Frontier Markets: Evidence from GCC. Journal of International Financial Markets, Institutions \& Money, 22, 538- 554. http://dx.doi.org/10.1016/j.intfin.2012.01.004 
Boehme, R., Danielsen, B., Kumar, P., \& Sorescu, S.(2009). Idiosyncratic Risk and the Cross Section of Stock Returns: Merton (1987) meets Miller (1977). Journal of Financial Markets, 12, 438-468. http://dx.doi.org/10.1016/j.finmar.2009.01.004

Campbell, J., Lettau, M., Malkiel, B., \& Xu, Y. (2001). Have Individual Stocks Become More Volatile? An Empirical Exploration of Idiosyncratic Risk. Journal of Finance, 56, 1-43. http://dx.doi.org/10.1111/0022-1082.00318

Chua, C., Goh, J., \& Zhang, Z. (2010). Expected Volatility, Unexpected Volatility and the Cross Section of Stock Returns. Journal of Financial Research, 33(2), 103-123. http://dx.doi.org/10.1111/j.1475-6803.2010.01264.x

Fama, E., \& French, K. (1992). The Cross-section of Expected Stock Returns. Journal of Finance, 48, 427-465. http://dx.doi.org/10.1111/j.1540-6261.1992.tb04398.x

Fama, E., \& French, K. (1993). Common Risk Factors in the Returns on Stocks and Bonds. Journal of Financial Economics, 33, 3-56. http://dx.doi.org/10.1016/0304-405X(93)90023-5

French, K., Schwert, G., \& Stambaugh, R. (1987). Expected Stock Returns and Volatility. Journal of Financial Economics, 19, 3-29. http://dx.doi.org/10.1016/0304-405X(87)90026-2

Fu, F.(2009). Idiosyncratic Risk and the Cross-Section of Expected Stock Returns.Journal of Financial Economics,Vol. 91, pp. 24.37. http://dx.doi.org/10.1016/j.jfineco.2008.02.003

Goyal, A., \& Santa-Clara, P.(2003). Idiosyncratic Risk Matters!. Journal of Finance, 58, 975.1007. http://dx.doi.org/10.1111/1540-6261.00555

Guo, H., \& Savickas, R. (2010). Relation between Time-Series and Cross-Sectional Effects of Idiosyncratic Variance on Stock Returns. Journal of Banking and Finance, 34(7), 1637-1649. http://dx.doi.org/10.1016/j.jbankfin.2010.03.010

Jegadeesh, N., \& Titman, S. (2001). Profitability of Momentum Strategies: An Evaluation of Alternative Explanations. Journal of Finance, 56, 699-720. http://dx.doi.org/10.1111/0022-1082.00342

Lintner, J. (1965). The Valuation of Risk Assets and the Selection of Risky Investments in Stock Portfolios and Capital Budgets. Review of Economics and Statistics, 47, 13-37. http://dx.doi.org/10.2307/1924119

Marcelo, J. L. M., Quirós, M. M. M., \& Quirós, J. L. M. (2012). Asset Pricing with Idiosyncratic Risk: The Spanish Case. International Review of Economics and Finance, 21, 261-271. http://dx.doi.org/10.1016/j.iref.2011.07.004

Markowitz, H. (1959). Portfolio Selection: Efficient diversification of Investments. New York: Wiley.

Merton, R. (1987). A Simple Model of Capital Market Equilibrium with Incomplete Information. Journal of Finance, 42, 483-510. http://dx.doi.org/10.1111/j.1540-6261.1987.tb04565.x 


\section{Macrothink}

Newey, W.K., \& West K.D. (1987). A Simple, Positive-Definite, Heteroskedasticity and Autocorrelation Consistent Covariance Matrix. Econometrica, 55, 703-708. http://dx.doi.org/10.2307/1913610

Sharpe, W. (1964). Capital Asset Prices: A Theory of Market Equilibrium. Journal of Finance, 19, 425-442. http://dx.doi.org/10.1111/j.1540-6261.1964.tb02865.x

Spiegel, M., \& Wang, X. (2006). Cross-sectional Variation in Stock Returns: Liquidity and Idiosyncratic Risk. Unpublished working paper, Yale University.

Treynor, J. L. (1961). Toward a Theory of Market Value of Risky Assets. Mimeo, subsequently published in Korajczyk, Robert A. 1999, Asset Pricing and Portfolios Performance: Models, Strategy and Performance Metrics London: Risk Books.

\footnotetext{
i Macroeconomic indicators used as control variable by Goyal and Clara (2003) were dividend price ratio, three-month Treasury bill rate, term Spread and default Spread.

ii Firm characteristics i.e. size, value, volume, liquidity, momentum, analyst forecast dispersion and market conditions.

iii The factors (SMB, HML and ERm) were calculated using the Fama French (1993) methodology which is described in section 2.1 of the study.
} 